\title{
The work environment and leadership in nursing: an integrative review*
}

\author{
AMBIENTE DE TRABALHO E A LIDERANÇA DO ENFERMEIRO: UMA REVISÃO \\ INTEGRATIVA
}

\section{AMBIENTE LABORAL Y LIDERAZGO DEL ENFERMERO: UNA REVISIÓN INTEGRATIVA}

\author{
Alexandre Pazetto Balsanelli ${ }^{1}$, Isabel Cristina Kowal OIm Cunha²
}

\begin{abstract}
Objective: To investigate the relationship between the work environment and leadership in nursing. Methodology: An integrative review of literature which was based on data from LILACS, PubMed, CINAHL and the SCiELO portal for journals covering the period from January to April 2013. The inclusion criteria were: the indexing of research covering leadership exercised by nurses over a team and whether the research was available in English, Spanish or Portuguese. Results: The sample consisted of 12 articles that met the criteria. Conclusion: The results showed that leadership had an impact on the work environment. However, no studies were found that showed the influence of the working environment on leadership in nursing.
\end{abstract}

\section{DESCRIPTORS}

Working environment Health Facilities

Leadership

Nursing

Review

\section{RESUMO}

Objetivo: Verificar a relação entre ambiente de trabalho e a liderança do enfermeiro. Método: Revisão integrativa da literatura cujo levantamento foi realizado nas bases de dados LILACS, PubMed, CINAHL e no portal de revistas SciELO, no período de janeiro a abril de 2013. Os critérios de inclusão foram: indexação no período de 2006 a 2013, que trabalhassem a relação entre ambiente de trabalho com a liderança exercida pelo enfermeiro na condução de sua equipe e que estivessem disponíveis nos idiomas inglês, espanhol e português. Resultados: A amostra constituiu-se de 12 artigos que atenderam os critérios estabelecidos. Conclusão: Os resultados mostram que a liderança causa impacto no ambiente de trabalho, entretanto, não foram encontrados estudos que mostrassem a influência do ambiente de trabalho na liderança do enfermeiro.

\section{DESCRITORES \\ Ambiente de trabalho \\ Instituições de Saúde \\ Liderança \\ Enfermagem \\ Revisão}

\begin{abstract}
RESUMEN
Objetivo: Verificar la relación entre el ambiente laboral y el liderazgo del enfermero. Método: Revisión integrativa de la literatura cuyo inventario fue llevado a cabo en las bases de datos LILACS, PubMed, CINAHL y en el portal de revistas SciELO, en el período de enero a abril de 2013. Los criterios de inclusión fueron: indexación en el período de 2006 a 2013, que trabajase la relación entre el ambiente laboral y el liderazgo ejercido por el enfermero en la conducción de su equipo y que estuviese disponible en los idiomas inglés, español y portugués. Resultados: La muestra se constituyó de 12 artículos que atendieron a los criterios planteados. Conclusión: Los resultados muestran que el liderazgo causa impacto en el ambiente laboral. Sin embargo, no se encontraron estudios que mostrasen la influencia del ambiente laboral en el liderazgo del enfermero.
\end{abstract}

DESCRIPTORES
Ambiente de trabajo
Instituciones de Salud
Liderazgo
Enfermería
Revisión

\footnotetext{
* Based on the thesis: "Liderança do enfermeiro em UTI e sua relação com o ambiente de trabalho", Escola Paulista de Enfermagem, Universidade Federal de São Paulo, 2014. ${ }^{1} \mathrm{PhD}$ in Sciences at the Postgraduate Program, Escola Paulista de Enfermagem, Universidade Federal de São Paulo, SP, Brasil. 2 Associate Professor at the Department for Administration in Collective Healthcare, Escola Paulista de Enfermagem, Universidade Federal de São Paulo, São Paulo, SP, Brasil
}

$\begin{aligned} & \text { Rev Esc Enferm USP } \text { 2014; 48(5):934-40 } \\ & \text { www.ee.usp.br/reeusp/ }\end{aligned} \quad \begin{aligned} & \text { Received: 04/16/2014 } \\ & \text { Approved: 08/11/2014 }\end{aligned}$




\section{INTRODUCTION}

Leadership is a skill that merits ongoing research. Several reasons contribute to this assertion. First of all, in the context of health services, this is due to the nature of the discussions which have been about the optimization of resources with the highest quality of services offered. Secondly, this is due to the expectations of organizations on the role of the leader in managing his team in pursuit of common objectives. In addition, as a consequence of the above, there is a need to satisfy the customer to ensure a sustainable system.

The Head Nurse is highly involved in these steps. As a leader he should seek to develop people so that the organization of which they are a part will be able to provide a good level of service.

However, leadership is a complex phenomenon, which should be looked at from three angles: the behavior/personality of the leader, the context in which this skill comes to the fore and who are the ones being led ${ }^{(1)}$. Based on the aforementioned assertion it is possible to identify the variables that influence leadership and impact strategic areas so that this skill can be exercised in an efficient and effective manner.

In this study, the focus of attention was on the place where the Head Nurse carries out his leadership role. The working environment is the place that allows this professional to demonstrate his knowledge, skills, and attitudes and to achieve pre-established objectives.

Interest in this area has existed since 1980, when the American Association of Nurses (ANA) noted that some hospitals had the ability to recruit and retain nurses, being referred to as magnets because of this ability. This attracted the interest of a number of researchers who wanted to know more about the organizational characteristics of these institutions. Autonomy, control over practices and collaborative relations were noted as crucial points in order to keep professionals motivated ${ }^{(2)}$.

The presence of the attributes mentioned above contributed to the reduction in the mortality rates of patients, which tended to be $4.8 \%$ lower in magnet hospitals in comparison to others ${ }^{(3)}$. However, the increase of one patient per nurse raised the burnout level to $23 \%$, dissatisfaction to $15 \%$ and the mortality rate to $7 \%^{(4)}$.

Patients admitted to units that have nursing teams which have: a sufficient number of staff and an administrative structure which fosters good relations between doctors and nurses, resulted in high levels of satisfaction with reference to the care received and low levels of burnout rates amongst employees ${ }^{(5)}$. This positive assessment from the client was also related to the environment of job practices and with the leadership in nursing ${ }^{(6)}$.

Based on this result, the relationship between the working environment and leadership should be investigated further. This is due to the fact that, at work, nurses are induced to use their competencies based on their own objectives and on what the organization expects of their performance.

Based on this perspective, a systematic review has shown that leadership style exerts a positive or negative influence on the work environment ${ }^{(7)}$. Another study(8) showed that institutions with effective leadership obtained the benefits of increased ties amongst employees, lower employee turnover, fewer conflicts, a greater involvement of people in the work process and better use of resources.

Having studied the practices of leadership and the intention of nurses to remain in their current positions, what we saw was a positive relationship between transformational leadership, working environments and the intentions of nurses to remain in their current positions $^{(9)}$.

The three reviews listed above ${ }^{(7-9)}$ showed that leadership produced impacts on the work environment. However, confirming whether this environmental influences the exercise of leadership by nurses constitutes a lacuna in the literature. Therefore, considering the experience of recent years, the problem raised by this study was as follows: What is the relationship between the work environment and leadership in nursing?

The response to this question will allow managers to plan actions for the development of leadership, giving consideration or not to the variable working environment, as well as contributing to the development of the production of knowledge in this area.

Thus, this study aims to investigate the relationship between the work environment and leadership in nursing.

\section{METHOD}

The study adopted an integrative literature review, a method that facilitates the preparation of a synthesis of the results of studies with similar or identical themes in order to develop a comprehensive explanation of a specific phenomenon. The stages in this review were: problem formulation, data collection, evaluation, data analysis and interpretation; presentation of results and conclusions ${ }^{(10)}$.

The survey of cataloged publications was carried out in the period from January to April 2013, in the following databases: Latin American and Caribbean Literature in Health Sciences (LILACS); Publisher Medline (PubMed); Cumulative Index to Nursing and Allied Health Literature (CINAHL); and the internet portal for journals of the Scientific Electronic Library Online (SciELO).

The search for articles in LILACS, PubMed, CINAHL and SciELO was performed using the health terminology defined in: the CINAHL Information Systems - List of Topical Subheadings; the Health Sciences Descriptors (DeCS/ BIREME); and the Medical Subject Headings (MeSH/ 
PubMed), respectively, which identified the following descriptors: health facility environment, work environment, nurse physician relations, job autonomy, organization and administration, leadership and nursing.

The inclusion criteria defined were: articles indexed in the last seven years (from January 2006 to December 2013), that addressed the relation of the work environment to the leadership provided by nurses in the management of their teams and which were available in the languages: English, Spanish and Portuguese.

The study identified 127 articles, of which 53 were excluded because they were duplicated in PubMed and SciELO when compared to those contained in CINAHL. In addition, 36 were excluded because abstracts were not available. After reading the abstracts of the remaining articles, a further 25 were eliminated due to their not meeting the inclusion criteria for the study. Although they addressed the work environment it was only from the point of view of physical and ergonomic structure. Also rejected was research that addressed the work environment, but not the relationship with the Head Nurse's leadership role. Following this the remaining articles were read carefully in full. Finally, the corpus of the integrative review consisted of 12 articles.

The analysis was carried out considering:

1. Name of Publication, year and language;

2. Sub-categories of original articles, as shown in Figure 1

\section{Integrative Review}

Problem: "What is the relationship between the work environment and the Head Nurse's leadership role?"

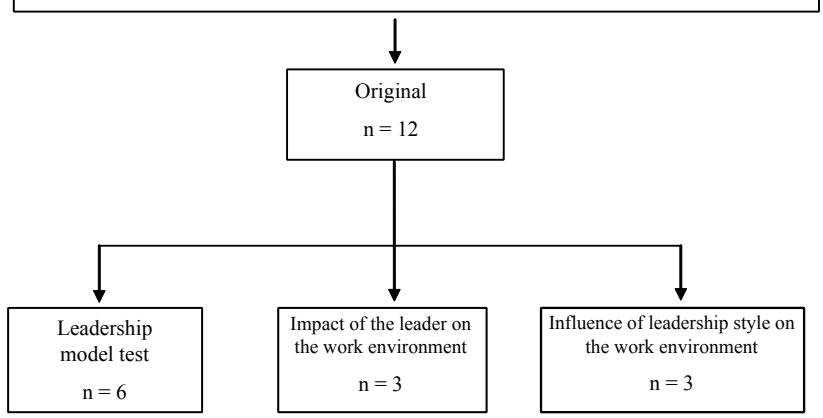

Figure 1 - Sample Analysis - São Paulo, SP, Brazil, 2013.

\section{RESULTS}

Chart 1 lists the 12 articles, classified by author, journal of publication, year, language and classification subcategory.

In the following paragraphs the studies will presented and discussed, according to the classification used (Figure 1). Considering the issues involved, three subcategories emerged: tests of leadership models $(n=6)$, that observed the influence of the leader's behavior on the work environment $(n=3)$ and the influence of leadership style on the work environment $(n=3)$, which are shown below.

Chart 1 - Distribution of references included in the integrative review - São Paulo, 2013

\begin{tabular}{|c|c|c|c|c|}
\hline Authors & Name of publication & Year & Language & Sub-category \\
\hline Wong CA, Laschinger $\mathrm{HKS}^{(11)}$ & Journal of Advanced Nursing & 2012 & English & Leadership model test \\
\hline Laschinger HKS, Smith LM $^{(12)}$ & Journal of Nursing Administration & 2013 & English & Leadership model test \\
\hline Laschinger HKS, Finegan J, Wilk $\mathrm{P}^{(13)}$ & Journal of Nursing Administration & 2009 & English & Leadership model test \\
\hline Laschinger HKS, Finegan J, Wilk $\mathrm{P}^{(14)}$ & Nursing Research & 2011 & English & Leadership model test \\
\hline Greco P, Laschinger HKS, Wong $\mathrm{C}^{(15)}$ & Nursing Research & 2006 & English & Leadership model test \\
\hline $\begin{array}{l}\text { Lankshear S, Kerr MS, Laschinger } \\
\text { HKS, Wong } \mathrm{CA}^{(17)}\end{array}$ & Health Care Management Review & 2012 & English & Impact of the leader on the work environment \\
\hline $\begin{array}{l}\text { McGilton KS, Hall LM, Boscart V, } \\
\text { Brown } \mathbf{M}^{(18)}\end{array}$ & Nursing Research & 2007 & English & Impact of the leader on the work environment \\
\hline Hall DS ${ }^{(19)}$ & Nursing Administration Quarterly & 2007 & English & Impact of the leader on the work environment \\
\hline $\begin{array}{l}\text { Alimo-Metcalfe B, Alban-Metcalfe J, } \\
\text { Bradley M, Mariathasan J, Samele } C^{(20)}\end{array}$ & $\begin{array}{l}\text { Journal of Health Organization and } \\
\text { Management }\end{array}$ & 2008 & English & $\begin{array}{l}\text { Influence of leadership style on the } \\
\text { work environment }\end{array}$ \\
\hline Lee D, Coustasse A, Sikula A ${ }^{(21)}$ & Health Care Management Review & 2011 & English & $\begin{array}{l}\text { Influence of leadership style on the } \\
\text { work environment }\end{array}$ \\
\hline $\begin{array}{l}\text { Casterlé BD, Willemse A, Verschueren } \\
\text { M, Milisen } \mathrm{K}^{(22)}\end{array}$ & Journal of Nursing Management & 2008 & English & $\begin{array}{l}\text { Influence of leadership style on the } \\
\text { work environment }\end{array}$ \\
\hline
\end{tabular}

\section{Leadership model tests $(n=6)$}

A model was tested that linked the real-life leadership of managers with the staff nurses' perception within a structure of empowerment, performance and job satisfaction ${ }^{(11)}$. The sample consisted of 280 staff nurses who responded to the data collection questionnaires for each of the varia- bles being studied. There was a positive, and significantly proven, influence of real-life leadership on the structure of empowerment, performance and job satisfaction ${ }^{(11)}$.

Therefore, it was proven that leadership style played a key role in job satisfaction ${ }^{(11)}$; and that empowerment is a strategy that can create positive working environments in nursing ${ }^{(12)}$. 
The perception of recently graduated staff nurses was also a focus of analysis. This study aimed to investigate the integration of real-life leadership, empowerment and inter-professional collaboration from the perspective of this group of professionals ${ }^{(12)}$. The results suggested that reallife leadership and the structure of empowerment could promote inter-professional collaboration in the work practices of these employees ${ }^{(12)}$.

Power was the subject of another investigation ${ }^{(13)}$, that proposed to test a leadership model at two levels: 1) Individual level - in which psychological empowerment is central, being positively related to organizational commitment and influenced by self-assessment; 2) Work unit level - the switching of positions between the leader and his subordinate favored an empowerment structure and these two variables influenced psychological empowerment and organizational commitment.

This study had the participation of 3,156 nurses from 217 hospitals in Ontario, Canada. The results showed that both constructs, a switch between the leader and his subordinate and the empowerment structure, had a significant and positive effect on psychological empowerment and organizational commitment. It also highlighted the importance of leadership in creating conditions that resulted in committed work environments ${ }^{(13)}$.

Another study tested a model to examine the effect of leadership and empowerment structure on occurrences of burnout and the nurses' job satisfaction, considering personal disposition and self-assessment of these individuals ${ }^{(14)}$.

The sample consisted of 3,156 nurses from 217 hospitals in Ontario, Canada, who answered questionnaires which had been validated for the investigated variables (switch between leader and subordinate, empowerment structure, burnout, self-evaluation and job satisfaction nucleus). The results showed that the possibility of a switch between the leader and his subordinate positively influenced the empowerment structure, which significantly increased job satisfaction. Furthermore, the occurrence of burnout was lower in this situation ${ }^{(14)}$.

Another study sought to examine a model that related the behavior of the leader's power (characterized by involvement in decision making, expressed confidence, facilitation of targets and promotion of fairness); the team's perception of the empowerment structure (information, research, support, opportunity, formal and informal power), areas of life at work (workload, control, reward, community, fairness and values) and burnout/ engagement or organizational commitment (emotional exhaustion/energy) $)^{(15)}$. The study had the participation of 322 nurses from various hospitals in Ontario, Canada. The analysis of the results supported a model in which the impact of the leader's attitude to power on burnout/engagement was fully mediated by the empowerment structure and the six areas of life at work ${ }^{(15)}$.
The last study ${ }^{(16)}$ in the group aimed to verify the relationship between the supervisor's leadership style, the perceived organizational support, trust in the leader, trust in the organization and burnout for 273 nurses in a public hospital in Italy.

The leadership style of the supervisor and the perception of organizational support by nurses correlated positively. There was a negative effect of the first variable with burnout through the mediation of trust in the leader and trust in the organization ${ }^{(16)}$.

This finding suggested that, for the leader to exercise his role well, he needed followers, that is, people who were inspired to pursue the same goals. To achieve this, trust was paramount. This is a value which was earned on a day-to day basis. However, there was a relationship between this practice and the satisfaction of the employees who worked with him.

\section{Impact of the leader on the work environment $(n=3)$}

For this subcategory, the studies that stood out were those that sought to examine how the leader influenced the work environment, that is, whether his personal characteristics contributed to a healthy work climate, or not, for the development of nursing work practices.

The first article ${ }^{(17)}$ aimed to examine the role of organizational power and personal influence on the creation of high quality environments for nursing job practices. Subjects from 45 hospitals participated in the survey.

The results indicated that there was a direct relationship between the professional practice of leadership, organizational power, the exercise of this function by the leader and healthy work environments ${ }^{(17)}$.

The evidence generated in this work showed the importance of organizational power and personal influence in contributing to the ability of these job practice leaders to achieve the desired results ${ }^{(17)}$.

A multi-center study(18) examined the relationship between the support of the directors, the stress level of nursing supervisors and job satisfaction. It was found that $45 \%$ of the nurses' job satisfaction was explained by the supervisor's support and, the higher the level of support, the lower the level of work stress.

The connection between the supervisor's support and the nurses' work performance was investigated at three units of a teaching hospital(19). Nurses with a high level of supervisor support achieved better results at work, with less stress, low turnover, fewer somatic complications, particularly related to gastrointestinal complaints, and a low level of absenteeism. The evidence from the studies presented ${ }^{(17-19)}$ showed the degree to which the leader was a good or bad influence on his team. 


\section{Influence of leadership style on the work environment $(n=3)$}

The first study ${ }^{(20)}$ of this subcategory sought to test the following hypothesis: high quality leadership can be positively associated with positive attitudes and well-being of the team at work, and also with the achievement of organizational goals.

The study found that there was a differential relationship between the quality of leadership and the attitudes of his team at work and its sense of well-being; and there was a predictive association between the quality of leadership and organizational performance ${ }^{(20)}$. It is worth noting that even though there was not a direct relationship with the work group, the study ${ }^{(20)}$ showed that the institutional results were achieved depending on how leadership was exercised. In fact, companies are made of people imbued by common aspirations that must converge to the same end.

Moreover, when the association of transformational leadership with accidents and absenteeism among 2,882 nursing assistants was analyzed, it was found that the adoption of this style of leadership led to an improvement in these indicators ${ }^{(21)}$.

In this same vein, when describing the development of a transformational leadership program and its impact on the clinical leader, on the nursing team and on the provision of care, the authors ${ }^{(22)}$ reported that this was an ongoing and interactive process between the clinical leader and his fellow work colleagues. Based on a focus group of 17 nurses, it was noted that they became more effective in the areas of self-assessment, communication skills, performance and vision. The nursing team gained from this, because leadership development promoted effective communication, greater responsibility, empowerment and transparency at work. Improving the clinical leadership influenced patient-centered communication, continuity of care and interdisciplinary collaboration ${ }^{(22)}$.

\section{DISCUSSION}

The analysis of the data showed that all the articles ${ }^{(11-22)}$ were published in English, and were carried out in research environments outside Brazil. This should instigate Brazilian researchers as to the importance of addressing the subject in the national context.

The review enabled the identification of some important findings that influence the nursing working environment and these are presented in the following paragraphs.

Leadership model tests have been an area of interest for researchers. In fact, investigating how a certain leadership style supports the exercise of leadership and the comparison with the intervening variables comprise a way to make the exercise of leadership more consolidated and structured.
The personal attributes of the leader imprint a special character on his style of leadership. The models indicated a direction, but the manner in which each one performed his management role was also influenced by his personal attributes.

The leader should always seek to share the management role, that is, facilitate the development of his team so that his subordinates can execute their tasks with a feeling of confidence, thereby making it possible to achieve their self-realization.

It is important that the nurse in a leadership position provide a structure that assists his group of subordinates to carry out their activities with autonomy and power. The relation with the interdisciplinary team, therefore, will focus on the customer and, as a result, the establishment of a good working environment.

This outlined the need for the Head Nurse to be concerned about his succession. When a subordinate takes on a strategic position, there is a great opportunity for professional development and growth. Thus, a vision of the future is created and one of the major goals of the leader has been reached, that is, that his working group surpass his own performance.

This fact was corroborated in two studies ${ }^{(13-14)}$ in which the switch between leader and subordinate showed positive results. This provided evidence, once again, to support the hypothesis that leadership, in general, had an influence on the organizational climate, guiding behavior and provided conditions for the group of employees to exercise their activities with commitment and strategic alignment.

Thus, the needs for the leader to promote ethical principles in daily work and to concern himself with the people in his team are indispensable conditions for his survival in the organization.

It is impossible to evaluate whether a work environment is healthy without analyzing the role of the manager. Therefore, equipping managers with the means to exercise leadership is increasingly necessary. Only when we devote ourselves to this end on a daily basis will we be able to achieve the proposed targets and, above all, provide employees with conditions conducive to the performance of their activities.

Influence of leadership style on the work environment is well-known. Its impacts can promote synergy or the disintegration of the team. Therefore, it is up to leaders to rethink the way they conduct their teams. Their attitudes are critical to the professional careers of their subordinates and also to the organization to which they belong

\section{CONCLUSION}

This review showed that leadership had an impact on the work environment, that is, it produced positive or negative results, depending on how this skill was exercised and practiced. 
However, the review did not confirm the existence of studies that demonstrated the influence of the work environment on the leadership role of the nurse. Therefore, it will be necessary to carry out new research in order to provide evidence on this relationship. Based on the identification of this lacuna in the literature and its eventual remediation, nursing managers should include the work environment as a variable or not in the development plan for this skill for the nurses under their responsibility. And, in addition, contribute to developing this theme.

\section{REFERENCES}

1. Firth-Cozens J, Mowbray D. Leadership and the quality of care. Qual Health Care. 2001;10 Suppl 2:ii3-7.

2. Cimiotti JP, Quinlan PM, Larson EL, Pastor DK, Lin SX, Stone PW. The magnet process and the perceived work environment of nurses. Nurs Res. 2005;54(6):384-90.

3. Aiken LH, Simith HL, Lake ET. Lower medicare mortality among a set of hospitals know for good nursing care. Med Care. 1994;32(8):771-87.

4. Aiken LH, Clarke SP, Sloane DM, Sochalski J, Silber JH. Hospital nurse staffing and patient mortality, nurse burnout, and job dissatisfaction. JAMA. 2002;288(16):1987-93.

5. Vahey DC, Aiken LH, Sloane DM, Clarke SP, Vargas D. Nurse burnout and patient satisfaction. Med Care. 2004;42(2 Suppl):II57-66.

6. Laschinger HKS, Leiter MP. The impact of nursing work environments on patient safety outcomes: the mediating role of burnout/engagement. J Nurs Adm. 2006;36(5):259-67.

7. Cummings GG, MacGregor T, Davey $M$, Lee $H$, Wong CA, Lo $E$, et al. Leadership styles and outcome patterns for the nursing workforce and work environment: a systematic review. Int J Nurs Stud. 2010;47(3):363-85.

8. Lanzoni GMM, Meirelles BHS. Leadership of the nurse: an integrative literature review. Rev Latino Am Enfermagem. 2011;19(3):651-8.

9. Cowden T, Cummings G, Profetto-McGrath J. Leadership practices and staff nurses' intent to stay: a systematic review. J Nurs Manag. 2011;19(4):461-77.

10. Whittemore R, Knafl $K$. The integrative review: updated methodology. J Adv Nurs. 2005;52(5):546-53.

11. Wong CA, Laschinger HKS. Authentic leadership, performance and job satisfaction: the mediating role of empowerment. J Adv Nurs. 2012;69(4):947-59.
A major focus of concern of the international literature was the testing of leadership models with variables of the working environment so that nurses would have role models to follow, and in which conditions they could be adopted.

In fact, the role of leadership needs to be investigated so that evidence is produced to support the nurse's work process and, in this way, contribute to the improvement of the daily exercise of this skill.

12. Laschinger HKS, Smith LM. The influence of authentic leadership and empowerment on new-graduate nurses' perceptions of interprofessional collaboration. J Nurs Adm. 2013;43(1):24-9.

13. Laschinger HKS, Finegan J, Wilk P. The impact of unit leadership and empowerment on nurses' organizational commitment. J Nurs Adm. 2009; 39(5):228-35.

14. Laschinger HKS, Finegan J, Wilk P. Situational and dispositional influences on nurses' workplace well-being. The role of empowering unit leadership. Nurs Res. 2011;60(2):124-31.

15. Greco $P$, Laschinger HKS, Wong $C$. Leader empowering behaviours, staff nurse empowerment and work engagement/ burnout. Nurs Res. 2006;19(4):41-56.

16. Bobbio A, Bellan M, Manganelli AM. Empowering leadership, perceived organizational support, trust, and job burnout for nurses: a study in an Italian general hospital. Health Care Manage Rev. 2012;37(1):77-87.

17. Lankshear S, Kerr MS, Laschinger HKS, Wong CA. Professional practice leadership roles: the role of organizational power and personal influence in creating a professional practice environment for nurses. Health Care Manage Rev. 2013;38(4):349-60.

18. MccGilton KS, Hall LM, Boscart V, Brown M. Effects of director of care support on job stress and job satisfaction among long-term care nurse supervisors. Nurs Res. 2007;20(3):5266.

19. Hall DS. The relationship between supervisor support and registered nurse outcomes in nursing care units. Nurs Adm Q. 2007;31(1):68-80.

20. Alimo-Metcalfe B, Alban-Metcalfe J, Bradley M, Mariathasan J, Samele $C$. The impact of engaging leadership on performance, attitudes to work and wellbeing at work: a longitudinal study. J Health Organ Manag. 2008;22(6):586-98. 
21. Lee D, Coustasse A, Sikula A. Transformational leadership and workplace injury and absenteeism: analysis of a national nursing assistant survey. Health Care Manage Rev. 2011;36(4):380-87.
22. Casterlé BD, Willemse A, Verschueren M, Milisen K. Impact of clinical leadership development on the clinical leader, nursing team and care-giving process: a case study. J Nurs Manag. 2008;16(6):753-63.

\section{Financial Support}

Coordinating Body for Training for Postgraduate Personnel (CAPES). Process number 008898340001-08. 